\title{
Experimental inoculation study indicates swine as a potential host for Hendra virus
}

\author{
Mingyi Li ${ }^{1 *}$, Carissa Embury-Hyatt ${ }^{1}$, Hana M. Weingartr ${ }^{1,2}$ \\ ${ }^{1}$ National Centre for Foreign Animal Disease, Canadian Science Centre for Human and Animal Health, \\ Canadian Food Inspection Agency, Winnipeg, Manitoba, Canada \\ ${ }^{2}$ University of Manitoba, Winnipeg, Manitoba, Canada
}

(Received 12 November 2009; accepted 18 January 2010)

\begin{abstract}
Hendra virus $(\mathrm{HeV})$ is a zoonotic virus from the family Paramyxoviridae causing fatal disease in humans and horses. Five-week-old Landrace pigs and 5-month-old Gottingen minipigs were inoculated with approximately $10^{7}$ plaque forming units per animal. In addition to fever and depression exhibited in all infected pigs, one of the two Landrace pigs developed respiratory signs at 5 days post-inoculation (dpi) and one of the Gottingen minipigs developed respiratory signs at 5 dpi and mild neurological signs at 7 dpi. Virus was detected in all infected pigs at 2-5 dpi from oral, nasal, and rectal swabs and at 3-5 dpi from ocular swabs by real-time RT-PCR targeting the $\mathrm{HeV} \mathrm{M}$ gene. Virus titers in nasal swab samples were as high as $10^{4.6} \mathrm{TCID}_{50} / \mathrm{mL}$. The viral RNA was mainly distributed in tissues from respiratory and lymphoid systems at an early stage of infection and the presence of virus was confirmed by virus isolation. Pathological changes and immunohistochemical staining for viral antigen were consistent with the tissue distribution of the virus. This new finding indicates that pigs are susceptible to $\mathrm{HeV}$ infections and could potentially play a role as an intermediate host in transmission to humans.
\end{abstract}

Hendra virus / Nipah virus / infection / swine / real-time RT-PCR

\section{INTRODUCTION}

Hendra virus (HeV), first described in 1994 as an equine morbillivirus, was identified as the cause of respiratory illnesses involving horses and two humans in the town of Hendra, a suburb of Brisbane, Australia. This outbreak resulted in the death of 13 horses and 1 human $[2,7]$. Sporadic cases of $\mathrm{HeV}$ infections have continued to occur in both horses and humans [2]. The outbreaks reported in 2008 and 2009 resulted in the death of 10 horses and 2 veterinarians [1] (ProMed Digest \#379, 390, 395, 398, 401, 409, and 413). Since 1994, 4 of the

\footnotetext{
* Corresponding author: Mingyi.Li@inspection.gc.ca
}

8 human cases of $\mathrm{HeV}$ infections were fatal [1] (ProMed Digest \#413). $\mathrm{HeV}$ is a zoonotic and Biosafety Level 4 (BSL4) agent. It is also listed as one of the potential biological agents for Bio-terrorism by the Atlantic Treaty Organization.

$\mathrm{HeV}$ belongs to a new genus, Henipavirus, in the Paramyxoviridae family together with Nipah virus (NiV), which was identified as a causative agent of human encephalitis in the 1998 outbreak in Malaysia [6, 10]. Limited in vivo studies have been done with both viruses due to the requirements for BSL4 facilities. Experimental $\mathrm{HeV}$ infections were performed in horses, cats, and guinea pigs all of which developed fatal disease during several trials. In contrast, rabbits and fruit bats developed

This is an Open Access article distributed under the terms of the Creative Commons Attribution-Noncommercial License (http://creativecommons.org/licenses/by-nc/3.0/), which permits unrestricted use, distribution, and reproduction in any noncommercial medium, provided the original work is properly cited. 
antibodies against $\mathrm{HeV}$ without any clinical signs [13].

In nature, $\mathrm{HeV}$ infections have been detected in horses, humans and bats, the latter being the natural reservoir host of the virus [5]. In a serological survey of 100 swine herds in Queensland, Australia [4], no anti-HeV antibodies were found in the 500 tested serum samples. Since pigs are susceptible to the closely related $\mathrm{NiV}$ and considered to be an intermediate host for this virus, the aim of this study was to determine whether pigs can also be susceptible to $\mathrm{HeV}$ infection, shed the virus and develop clinical disease characterized by pathological lesions.

\section{MATERIALS AND METHODS}

\subsection{Viruses and cells}

Human isolates of $\mathrm{HeV}$ and $\mathrm{NiV}$ were kindly provided by Thomas Ksiazek and Pierre Rollin (CDC, Atlanta, GA, USA). The $\mathrm{HeV}$ and NiV stocks were produced by infecting Vero-76 cell monolayers (American Type Culture Collection, Manassas, VA, USA) at a multiplicity of infection of 0.1 . Inoculated cells were then incubated at $37{ }^{\circ} \mathrm{C}$ for $72 \mathrm{~h}$ or until $80 \%$ of the monolayer exhibited a cytopathic effect. Aliquots of clarified (centrifugation at $2000 \times g$, $4{ }^{\circ} \mathrm{C}, 20 \mathrm{~min}$ ) supernatant were stored at $-150^{\circ} \mathrm{C}$. Virus titres were determined by virus plaque assay in Vero-76 cells as described previously [11].

\subsection{Animals and animal care}

Hartley guinea pigs (GP) with a body weight of approximately $500 \mathrm{~g}$ were obtained from Charles River Laboratories International Inc. (St. Constant, QC, Canada). Four-week-old Landrace pigs (P) were obtained from a high health status herd (Sunnyside Colony Ltd., Sunnyside, MB, Canada). Five-monthold female Gottingen minipigs (MP) were obtained from Marshall BioResources (North Rose, NY, USA). All animals were acclimatized for a minimum of one week prior to inoculation. All procedures involving live virus were performed under BSL4 conditions. Animal housing and manipulations met the Canadian Council on Animal Care guidelines and were approved by the Animal Care Committee of the Canadian Science Centre for Human and Animal Health.

\subsection{Animal experimental design and sample collection}

\subsubsection{Guinea pigs}

Six guinea pigs were inoculated intra-nasally with $3.4 \times 10^{6}$ plaque forming units (PFU) of $\mathrm{HeV}$ per guinea pig. Oral swabs and serum samples were collected on $0,2,6,8$ days post-inoculation (dpi). Swab samples were collected using polyester fiber swabs (BD, Sparks, MD, USA) emerged into $2 \mathrm{~mL}$ of Dulbecco's phosphate buffered saline (DPBS) (Sigma, St. Louis, MO, USA), supplemented with $100 \mathrm{IU} / \mathrm{mL}$ of Penicillin and $100 \mu \mathrm{g} / \mathrm{mL}$ of Streptomycin. Surviving animals were re-inoculated at $16 \mathrm{dpi}$ with the same dose as above and bled out by cardiac puncture on 25 dpi for serum collection.

\subsubsection{Landrace pigs}

Two Landrace pigs (P1-2) were inoculated oronasally with $6.6 \times 10^{7} \mathrm{PFU}$ of $\mathrm{HeV}$ per pig. Two control pigs were inoculated with DPBS and kept separately in a different cubicle.

Nasal, oral, ocular and rectal swabs as well as blood samples were collected on $0,2,4$, and 5 dpi. The following tissues were collected at the time of necropsy: nasal turbinates, trachea, lung, submandibular, bronchial, inguinal, mesenteric lymph nodes, tonsil, spleen, thymus, frontal lobe of the brain (forebrain), cerebellum, pons, thalamus, basal ganglia, medulla, olfactory bulb, meninges, optic nerve, tongue, heart, liver, kidney, bladder, colon, and duodenum. Bronchial-alveolar lavage fluid (BALF), cerebral spinal fluid (CSF) and urine were also collected. Blood, swabs and selected tissue samples were collected from control pigs on 0 and 6 dpi for analysis along with those from infected animals.

\subsubsection{Minipigs}

Five Gottingen minipigs (MP2-6) were inoculated intra-nasally only with $2.0 \times 10^{7} \mathrm{PFU}$ of $\mathrm{HeV}$ per pig, due to the tight jaw in this breed during anesthesia. MP6, MP5 and MP4 were sacrificed on 3, 5, and 7 dpi, respectively. MP3 and MP2 were re-inoculated on 13 dpi intra-nasally with the same dose of $\mathrm{HeV}$ for antiserum production and kept until 20 and 21 dpi, respectively. Four control minipigs were kept separately in a different cubicle. Blood and swab samples were collected at $0,3,5,7,13,20$ or $21 \mathrm{dpi}$. A set of tissue and fluid samples corresponding to the set collected from the Landrace pigs was collected at 
necropsy. For these animals, individual lung lobes were harvested instead of the BALF.

\subsection{Histology and immunohistochemistry (IHC)}

Tissues collected from pigs and minipigs were fixed in $10 \%$ formalin for a minimum of 5 days and trimmed inside a BSL4 lab. These tissues were left in $10 \%$ formalin for an additional $24 \mathrm{~h}$ before removal from BSL4. Paraffin embedded tissue sections were stained with hematoxylin and eosin (HE) according to standard protocols. Immunohistochemistry was conducted using the protocols described elsewhere [11] with monoclonal antibodies against NiV-N (mixture of F45G2, F45G3 and F45G6) [3].

\subsection{Homogenization of tissue samples}

The $10 \%(\mathrm{w} / \mathrm{v})$ tissue homogenates were prepared in cold, $\mathrm{Ca}^{2+}$ and $\mathrm{Mg}^{2+}$ free DPBS supplemented with 1\% Pen/Strep (Wisent Inc., St. Bruno, QC, Canada) by homogenization in a closed plastic bag using a MiniMix blender (Interscience Laboratory Inc., Rockland, MA, USA) for $30 \mathrm{~s}$ at a setting of 9 strokes per second. The homogenized tissues were clarified by centrifugation $(2000 \times g, 20 \mathrm{~min})$ and the supernatants were collected for analyses.

\subsection{RNA extraction and real-time RT-PCR}

\subsubsection{RNA extraction}

Total RNA was extracted from $100 \mu \mathrm{L}$ of the serum, swab, and tissue homogenates using TriPure Reagent (Roche Diagnostic Corporation, Indianapolis, IN, USA) as per the manufacturer's instructions. All samples were tested in duplicate. The final RNA pellets were re-suspended in $40 \mu \mathrm{L}$ of Nuclease-Free water (Ambion, Austin, TX, USA).

\subsubsection{Real-time RT-PCR}

Viral RNA was detected by semi-quantitative realtime RT-PCR (HeV-M rRT-PCR) using primers (Invitrogen Canada, Burlington, ON, Canada) and probe (Applied Biosystems Ltd., Foster City, CA, USA) targeting a coding region of the $\mathrm{HeV}$ matrix protein (M) with an amplification of a 69-bp product [9]. Real-time RT-PCR (rRT-PCR) assays were performed using the ABI Sequence Detection System model 7900HT (Taqman; Applied Biosystems Ltd.) with reagents from the QuantiTec Probe RT-PCR kit
(Qiagen, Mississauga, ON, Canada). Each reaction contained $5 \mu \mathrm{L}$ of template RNA in a final volume of $25 \mu \mathrm{L}$. The conditions for real-time RT-PCR were $30 \mathrm{~min}$ at $50^{\circ} \mathrm{C}$ and $15 \mathrm{~min}$ at $95^{\circ} \mathrm{C}$, followed by 45 cycles of $95{ }^{\circ} \mathrm{C}$ for $15 \mathrm{~s}$, and $60{ }^{\circ} \mathrm{C}$ for $60 \mathrm{~s}$.

\subsubsection{Plasmid DNA standard for quantification}

A pair of complemented forward (5'-TCGACT CTTCGACAAAGACGGAACCAATCTGGCATCT TTCATGCTCCATCTCGGCAGAAGACTGTGGA TGGCCCCTCTCAATTTTGTCCGACGAGCTGG G-3') and reverse (5'-AATTCCCAGCTCGTCGGA CAAAATTGAGAGGGGCCATCCACAGTCTTC TGCCGAGATGGAGCATGAAAGATGCCAGAT TGGTTCCGTCTTTGTCGAAGAG-3') oligonucleotides with binding sequences of $\mathrm{HeV}-\mathrm{M}$ primers and probe, were synthesized in order to generate a standard for real-time RT-PCR. The two oligonucleotides were denatured and re-annealed. The product with overhanging SalI and EcoRI ends was subsequently cloned into the respective sites in pGEM-Teasy plasmid (Promega Corporation, Madison, WI, USA) and transformed into Escherichia coli (DH5 $\alpha$ ) for the standard plasmid stock preparation. The correct nucleotide sequence of the cloned product was confirmed by sequencing and restriction enzyme digestion. The cloned plasmid DNA was prepared using the Qiagen plasmid purification kit and quantified using a NanoDrop ND1000 spectrophotometer (Thermo Scientific, Wilmington, DE, USA). A series of 10-fold dilutions of the plasmid DNA were prepared and dilutions with copy numbers ranging from $10^{1}$ to $10^{8}$ per reaction were used for quantification in HeV-M rRT-PCR. Samples with the number of copies (copy number) per reaction lower than $10^{2}$ (Cycle threshold $(\mathrm{Ct})$ value of 36.0) were considered negative.

\subsection{Virus isolation}

Virus isolations were performed on Vero-76 cell monolayers seeded in 96-well plates (Corning Costar Corporation) by end-point titration, from the same preparations used for HeV-M rRT-PCR. Ten-fold serial dilutions of the tissue homogenate supernatants, sera, or swab samples were made in Dulbecco's modified Eagles's medium (DMEM) (Sigma) and incubated on cells $(50 \mu \mathrm{L} /$ well $)$ for $1 \mathrm{~h}$ at $37^{\circ} \mathrm{C}, 5 \%$ $\mathrm{CO}_{2}$. Following the incubation, an equal volume of DMEM with $4 \%$ fetal bovine serum was added to each well. Plates were incubated for 3 days at $37{ }^{\circ} \mathrm{C}, 5 \% \mathrm{CO}_{2}$. The virus titer was determined in $50 \%$ tissue culture infective dose $\left(\mathrm{TCID}_{50}\right)$ calculated by the method of Reed and Muench [8]. 


\subsection{Indirect enzyme-linked immunosorbent assay (ELISA) for the detection of antibodies against $\mathrm{HeV}$}

Binary ethylenimine (BEI)-inactivated $\mathrm{HeV}$ was subjected to ultracentrifugation through a $30 \%$ sucrose cushion following procedures described elsewhere [3]. The resulting virus pellet was re-suspended in ice-cold DPBS and sonicated with a Microson ultrasonic cell disruptor (Misonix Inc., Famingdale, NY, USA). Aliquots of semi-purified virus (BEI$\mathrm{HeV}$ ) were stored at $-70{ }^{\circ} \mathrm{C}$ until further use.

Nunc ELISA plates were coated with BEI-HeV at $1.3 \mu \mathrm{g} /$ well in carbonate buffer, $\mathrm{pH} 9.6(100 \mu \mathrm{L} /$ well) and incubated overnight at $4{ }^{\circ} \mathrm{C}$. The plates were then blocked with $5 \%$ skim milk in phosphate buffered saline (PBS) for $1 \mathrm{~h}$ at $37{ }^{\circ} \mathrm{C}$. Pig serum samples, diluted 1:100 in 5\% skim milk in PBS with $0.05 \%$ Tween-20 (Sigma) (PBST), were then added $(100 \mu \mathrm{L} /$ well $)$ and incubated for $1 \mathrm{~h}$ at $37^{\circ} \mathrm{C}$. The ELISA plates were washed 5 times with PBST. Horse radish peroxidase (HRP)-conjugated goat antiporcine IgG antibody (Kirkegaard and Perry Laboratories Inc., Gaithersburg, MD, USA), diluted 1:1000 in $5 \%$ skim milk in PBST, was added $(100 \mu \mathrm{L} /$ well $)$ and incubated for $1 \mathrm{~h}$ at $37{ }^{\circ} \mathrm{C}$. The plates were washed as described above and $100 \mu \mathrm{L}$ of 2, 2azino-bis (3-ethylbenzothiazoline-6-sulphonic acid) (ABTS) solution (Roche Diagnostic Corporation), prepared according to the manufacturer's instructions, was added to the individual wells. The color development was measured at $405 \mathrm{~nm}\left(\mathrm{OD}_{405}\right)$ after $10 \mathrm{~min}$ of incubation.

\subsection{Plaque reduction neutralization test (PRNT)}

The level of $\mathrm{HeV}$-specific neutralizing antibody in heat-inactivated sera $\left(1 \mathrm{~h}, 56^{\circ} \mathrm{C}\right)$ was determined using the PRNT with Vero V-76 cells seeded into 24-well plates. Briefly, working virus solutions were made in cell culture medium with a target of 100 $\mathrm{PFU} /$ well. Mixtures of virus $(200 \mu \mathrm{L})$ and serial dilutions of swine serum $(200 \mu \mathrm{L})$ were incubated at $37^{\circ} \mathrm{C}$ for $1 \mathrm{~h}$ and then added to the cell monolayers in triplicate wells $(100 \mu \mathrm{L} /$ well $)$. After a $1 \mathrm{~h}$ incubation, the virus-serum mixture in each well was replaced with $1 \mathrm{~mL}$ of $1 \%$ carboxymethylcellulose (CMC) $/ 2 \%$ fetal bovine serum. The plates were incubated at $37{ }^{\circ} \mathrm{C}, 5 \% \mathrm{CO}_{2}$ for $2-3$ days followed by fixation with $4 \%$ formaldehyde and staining with $0.5 \%$ crystal violet in $80 \%$ methanol in PBS. Wells with $70 \%$ plaque reduction were considered positive for the presence of $\mathrm{HeV}$ neutralizing antibodies.
The sera were also tested in parallel for cross-neutralization with $\mathrm{NiV}$ using the same procedure.

\section{RESULTS}

\subsection{Guinea pigs}

Starting at 4 dpi all six guinea pigs, inoculated with $\mathrm{HeV}$, developed signs of depression (reduced feed and water intake, weight loss, and inactivity). One guinea pig was found dead at $5 \mathrm{dpi}$ with blood around the nares and another was found dead at 6 dpi. All surviving guinea pigs recovered at $9 \mathrm{dpi}$ and remained clinically healthy until the end of the experiment. These observations were consistent with previous reports $[14,16]$.

Viral RNA was detected by HeV-M rRTPCR in oral swabs from all six $\mathrm{HeV}$-infected guinea pigs at 2-6 dpi, however, the level peaked at different days for each animal. Interestingly, the infection was fatal for guinea pigs with viral RNA at $6.7 \times 10^{5}$ copies $/ \mathrm{mL}$ and higher in oral swabs, while guinea pigs with lower viral load survived until the termination of the experiment. Antibodies against $\mathrm{HeV}$ were detected in serum samples from infected guinea pigs at $8-25$ dpi by BEI-HeV ELISA ${ }^{1}$.

\subsection{Clinical observations in swine}

Both of the infected Landrace pigs exhibited increased rectal temperatures of $40.0-40.7^{\circ} \mathrm{C}$ and reduced feed intake at 4-5 dpi. Pig P1 was found in lateral recumbency with signs of severe depression and respiratory distress at $5 \mathrm{dpi}$ and both pigs were euthanized that day. No clinical signs of disease were observed in the control pigs.

According to the experimental schedule, inoculated minipigs MP6, MP5 and MP4 were sacrificed at 3, 5, and $7 \mathrm{dpi}$, respectively. A body temperature higher than $40{ }^{\circ} \mathrm{C}$ was observed only in minipig MP2 at 9 dpi. Minipig MP5 showed mild depression from 3 to 5 dpi (day of necropsy). Minipig MP2 developed signs of depression, cough, respiratory distress, and transient neurological signs (i.e., incoordination) at $7 \mathrm{dpi}$,

\footnotetext{
${ }^{1}$ Manuscript in preparation.
} 
Table I. Presence of microscopic lesions (HE) and antigen distribution (IHC) in organs of Hendra virus infected pigs.

\begin{tabular}{lccccccc}
\hline Animal \# & dpi & $\begin{array}{c}\text { Lung } \\
\text { HE/IHC }\end{array}$ & $\begin{array}{c}\text { Nasal } \\
\text { turbinates } \\
\text { HE/IHC }\end{array}$ & $\begin{array}{c}\text { Submandibular } \\
\text { LN HE/IHC }\end{array}$ & $\begin{array}{c}\text { Bronchial } \\
\text { LN HE/IHC }\end{array}$ & $\begin{array}{c}\text { Olfactory } \\
\text { bulb HE/IHC }\end{array}$ & $\begin{array}{c}\text { Tonsil } \\
\text { HE/IHC }\end{array}$ \\
\hline MP6 & 3 & $+/-$ & $-/+$ & $+/+$ & $-/-$ & $-/-$ & $-/-$ \\
P1 & 5 & $+/+$ & $-/-$ & $+/+$ & $+/+$ & $\mathrm{ns}$ & $+/+$ \\
P2 & 5 & $+/+$ & $+/-$ & $+/+$ & $+/+$ & $\mathrm{ns}$ & $+/+$ \\
MP5 & 5 & $+/+$ & $-/-$ & $-/-$ & $-/-$ & $+/-$ & $-/-$ \\
MP4 & 7 & $+/-$ & $+/+$ & $+/+$ & $-/-$ & $-/-$ & $-/-$ \\
\hline
\end{tabular}

* Presence of histological lesions/positive immunostaining for viral antigen.

- Negative; + positive; dpi: days post-inoculation; ns: tissue not submitted; and LN: lymph nodes.

from which it recovered the next day, although depression and cough lasted three additional days. Minipig MP2 and MP3 were clinically healthy after 10 dpi. Minipigs from the control groups showed no clinical signs.

\subsection{Histopathology and immunohistology}

At necropsy, pig P1 had petechial hemorrhages on kidneys and consolidated lungs. No remarkable changes were observed for pig P2. Minipig MP5 had petechial hemorrhages in multiple organs, including lungs, bronchial and submandibular lymph nodes. Minipig MP4 had areas of consolidation and dark red demarcated areas (hemorrhages) distally on both lung halves.

The presence of histological lesions and their relationship to the detection of viral antigen is summarized in Table I. Histological lesions were minimal in minipig M6 at $3 \mathrm{dpi}$, and consisted of mild pulmonary edema and the presence of multinucleated syncytial cells in the submandibular lymph node. Viral antigen was detected by immunohistochemistry in a few respiratory epithelial cells of the nasal turbinates as well as endothelial cells, lymphocytes, macrophages and dendritic reticular cells in the submandibular lymph nodes.

At 5 dpi (minipig MP5), mild to moderate edema was observed in most lung sections examined; however there was only one small focus of inflammation in the bronchiolar epithelium with an occasional formation of multinucleated syncytial cells. Antigen was detected in the bronchial and bronchiolar epithelium of the lung (Fig. 1A). Vasculitis was observed in arteries adjacent to these affected airways.

At 7 dpi in minipig MP4, mild to moderate pulmonary edema could still be observed in some sections of the lung but no other lung lesions were observed and no antigen was detected at this time point.

Occasional patches of degeneration of the respiratory epithelial cells and several respiratory epithelial syncytial cells (Fig. 1B) with positive antigen staining were observed in the respiratory epithelium of nasal turbinates. Lesions in the submandibular lymph nodes consisted of scattered multinucleated syncytial cells in areas surrounding connective tissue trabecule. There was extensive immunostaining concentrated around vessels and connective tissue trabecule within the lymph nodes (Fig. 1C).

Most of the lesions in the infected Landrace pigs ( $\mathrm{P} 1$ and $\mathrm{P} 2$ ), at $5 \mathrm{dpi}$, were similar to those observed in the minipigs. However, the severity of lesions and viral antigen distribution were more extensive within the lungs and bronchial lymph nodes than those in minipigs. Lesions in the lungs were characterized by a severe interstitial pneumonia. Alveoli were filled with numerous macrophages, fibrin, neutrophils, plasma cells and lymphocytes, as well as numerous necrotic syncytial cells. Spongiosis and necrosis with attenuation as well as bronchiolar syncytial cells were observed in the bronchiolar epithelium (Fig. 1D). Antigen was detected within alveolar macrophages, bronchiolar epithelial cells, alveolar and bronchiolar syncytial cells (Fig. 1E). 


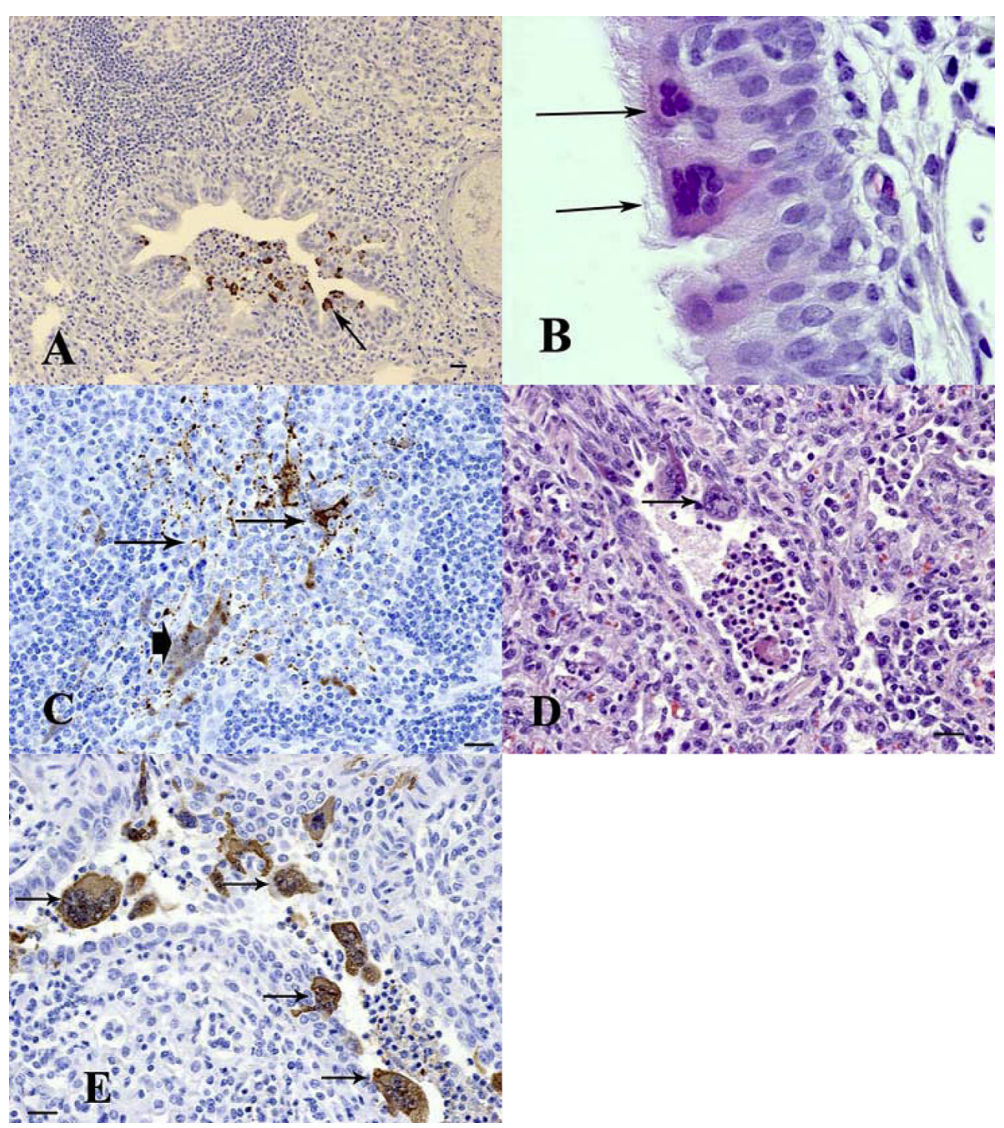

Figure 1. Histopathological changes and the presence of viral antigen in pigs experimentally infected with Hendra virus. (A) Lung (minipig MP5): 5 dpi. Viral antigen was detected in epithelial cells of bronchioles (arrow). (B) Nasal Turbinate (minipig MP4): 7 dpi. Formation of epithelial syncytial cells (arrows). (C) Submandibular lymph node (minipig MP4): 7 dpi. Viral antigen was observed within reticular dendritic cells (arrows) as well as multinucleated syncytial cells (arrowhead). (D) Lung (Landrace pig P1): 5 dpi. A bronchiole shows attenuation and necrosis of the epithelium and formation of syncytial cells (arrow). (E) Lung (Landrace pig P1): 5 dpi. Positive immunostaining was observed within bronchiolar epithelial syncytial cells (arrows). (B, D) Hematoxylin and eosin (HE) stain; (A, C, E) immunohistochemistry/DAB/ hematoxylin (IHC) staining. Bar $=20 \mu \mathrm{m}$. Magnification of $\mathrm{B}: \times 100$ objective (A color version of this figure is available at www.vetres.org).

Hemorrhage, neutrophil infiltration and numerous multinucleated cells were noted within bronchial lymph nodes, with antigen in macrophages, multinucleated cells and subcapsular lining cells.

Significant lesions and/or antigen were not observed in the trachea, mesenteric and inguinal lymph nodes, spleen, cerebellum, medulla, fore- brain, kidney, duodenum, colon, or thymus from any of the animals examined.

\subsection{Viral RNA shedding}

Viral RNA was detected by rRT-PCR in all four types of swabs (oral, nasal, rectal and ocular) collected at 2-5 dpi from pigs P1 and P2, 
except for the ocular swab from pig P2 at 2 dpi (Figs. 2A-D). Greater variation in the presence of RNA in swabs was observed for minipigs, although they all had viral RNA present at some point (see Figs. 2A-D). Overall, viral loads in all four types of swabs were found in decreasing order for nasal, oral, rectal and ocular samples. Landrace pigs had notably higher viral loads in swabs than minipigs (Figs. 2A-D).

\subsection{Viral RNA distribution in tissues}

Tissues from $\mathrm{HeV}$-infected pigs were screened by real-time RT-PCR for the presence of viral RNA, prior to attempts for virus isolation. Viral RNA was detected in nasal turbinates, trachea, BALF, tonsil, submandibular and bronchial lymph nodes of both Landrace pigs P1 and $\mathrm{P} 2$, as well as in the tongue from pig P1 (Tab. II). Viral RNA was not detected in the remaining screened tissues, including different regions of the central nervous system (CNS).

In minipigs, nasal turbinates and submandibular lymph nodes from all three pigs sacrificed on 3, 5, and 7 dpi (MP6, MP5, and MP4) were positive for viral RNA. Viral RNA was also found in the trachea, right apical and left cardiac lobes of lungs, tonsils and bronchial lymph nodes of minipig MP5, while in minipig MP6 only tonsils and olfactory bulb were positive for the presence of viral RNA. The olfactory bulb was the only additional tissue with detectable levels of RNA in minipig MP4. An overview of the results is presented in Table II.

\subsection{Virus isolation}

Virus isolations were performed on samples positive during screening by $\mathrm{HeV}-\mathrm{M}$ rRT-PCR, and the rRT-PCR was repeated at the time of the attempted virus isolation. Virus was consistently isolated from samples that yielded 3.0 $\log _{10}$ copy number or higher per $12.5 \mu \mathrm{L}$ on the repeat (Tabs. III and IV): namely from tonsils, BALF, oral, nasal and rectal swabs of the Landrace pigs; from lung and olfactory bulbs of the miniature pigs, as well as nasal turbinates, submandibular and bronchial lymph nodes of both breeds. It was noted that copy numbers on repeats were lower than on the screening (data in Fig. 2 and Tab. II), following the additional freeze-thaw, which may have decreased detectable infectivity in the individual samples.

\subsection{Antibody development}

Serum samples collected from $\mathrm{HeV}$-infected pigs were analyzed by virus neutralization (PRNT) and indirect IgG ELISA using BEIinactivated virus as antigen. The Landrace pigs P1 and P2 developed antibodies against $\mathrm{HeV}$ antigen at as early as $5 \mathrm{dpi}$. The sera from minipigs MP6 and MP5, sacrificed at 3 and 5 dpi, were negative for antibodies against $\mathrm{HeV}$. The earliest time for detecting antibodies in the minipigs was at $7 \mathrm{dpi}$ in the three remaining infected animals (MP4, MP3 and MP2), with increasing OD values thereafter (Fig. 3). Neutralizing antibodies with titres from 20 to 160 were found only in sera collected after $7 \mathrm{dpi}$ (from minipigs MP3 and MP2). The sera cross-reacted with $\mathrm{NiV}$ at similar titers.

\section{DISCUSSION}

In this inoculation study, pigs from the commercial Landrace breed and the Gottingen minipig breed were able to be infected with $\mathrm{HeV}$ thereby providing a proof in principle for the establishment of animal disease models. In both breeds, early in the infection, virus was detected mainly in tissues from respiratory and lymphoid systems, which is consistent with previous findings in other animal species $[15,17]$. Virus was isolated from nasal, oral, and rectal swabs, indicating the possible routes for virus shedding. Isolation from ocular swabs was unsuccessful, although low copy numbers of viral RNA were detected. Unlike previous findings in other infected species (horse, guinea pig, and cat) $[15,17]$, the virus was likely not excreted through the urinary tract in infected pigs, based on negative findings in the urine, bladder, or kidney. Virus was not detected in either serum or blood (real-time RT-PCR and virus isolation), spleen, brain, uterus, liver and heart from infected pigs (data not shown), in contrast to guinea pigs and cats $[15,17]$. 

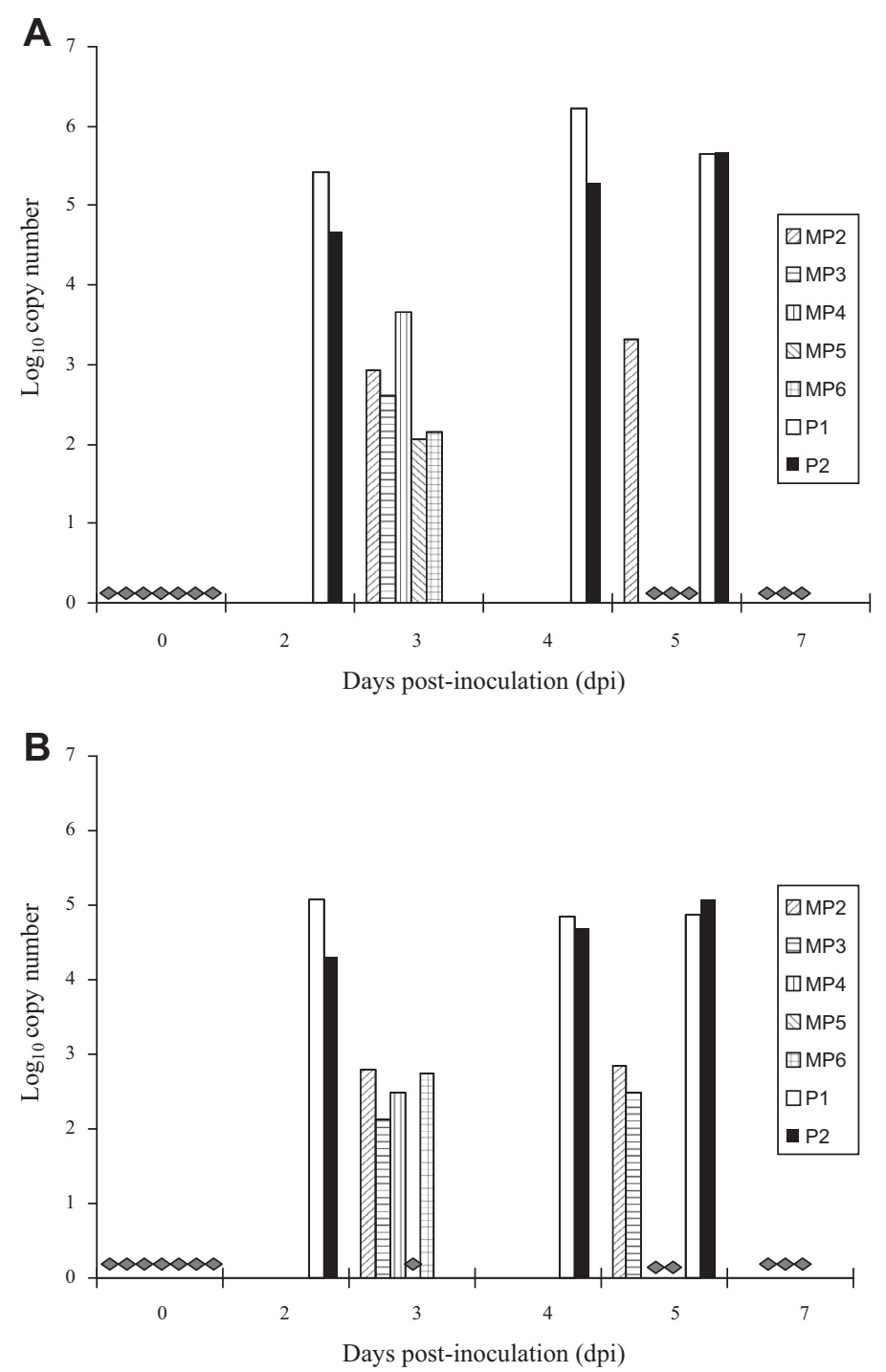

Figure 2. Real-time RT-PCR analysis of swabs from $\mathrm{HeV}$-infected pigs. Values presented as $\log _{10}$ copy number per $12.5 \mu \mathrm{L}$ of samples. Data displayed were averages from duplicates of each sample. (A) Nasal swabs; (B) oral swabs; (C) rectal swabs; (D) ocular swabs. Samples considered negative (2.0 $\log _{10}$ copy number or less per reaction) are indicated with grey diamonds.

The presence of $\mathrm{HeV}$ in the olfactory bulb of infected minipigs indicates that the virus may invade CNS, possibly through the olfactory pathway, although virus (or viral RNA) was not detected in different sections of the CNS. At this point, it appears that $\mathrm{HeV}$ may not invade the CNS in pigs the same way as NiV [11]. The clinical signs in the two infected Landrace pigs were more severe compared to those observed in minipigs. The Landrace pigs were very sick at $5 \mathrm{dpi}$, with one developing severe depression, respiratory distress and possible 

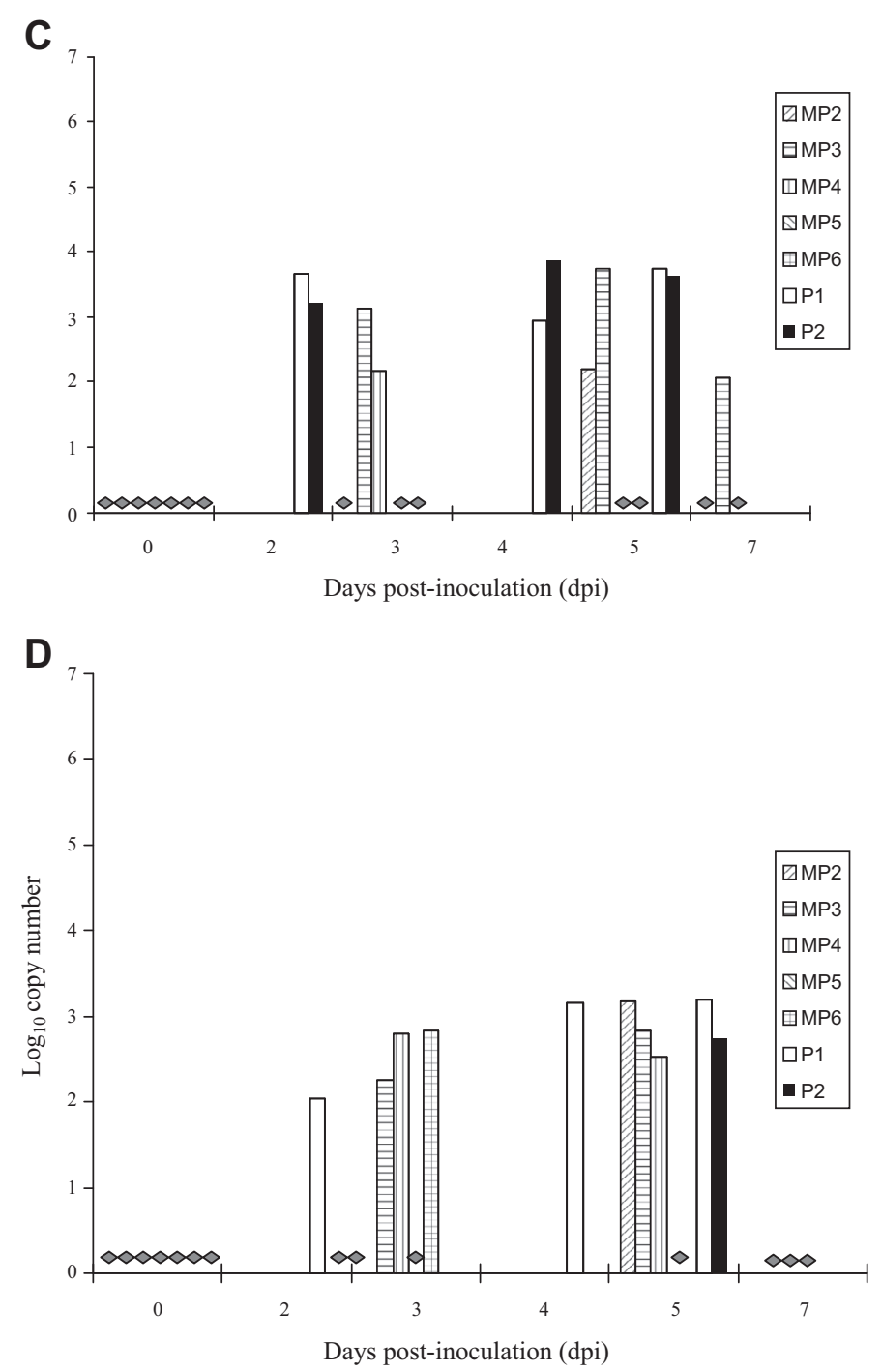

Figure 2. Continued.

neurological signs, requiring euthanasia. However, due to the small number of experimental animals, different ages ( 5 weeks for commercial pigs versus 5 months for minipigs), and different breeds it is difficult to draw any conclusions.

The infection of 5-week-old Landrace pigs with $\mathrm{HeV}$ appeared to lead to somewhat more severe clinical disease compared to NiV infection. However due to the considerably higher dose of $\mathrm{HeV}$ used for inoculation compared to
$\mathrm{NiV}$ (in the range of $10^{7}$ compared to $10^{5}$ PFU/animal, respectively), it is difficult to again draw conclusions at this point. Since we were initially not sure whether the pigs would be susceptible to $\mathrm{HeV}$, a higher dose was chosen. Follow-up infection studies would be needed to further investigate the virulence of $\mathrm{HeV}$ in pigs inoculated with a virus dose reflecting the level found in secretions (e.g., nasal) during natural shedding. 
Table II. Real-time RT-PCR screening of tissue samples from $\mathrm{HeV}$-infected pigs.

\begin{tabular}{|c|c|c|c|c|c|}
\hline Animal \# & MP6 & MP5 & $\mathrm{P} 1$ & $\mathrm{P} 2$ & MP4 \\
\hline dpi & 3 & 5 & 5 & 5 & 7 \\
\hline Nasal turbinates & 4.6 & 5.0 & 4.0 & 3.3 & 2.1 \\
\hline Trachea & - & 3.7 & 3.8 & 3.7 & - \\
\hline Lung & NA & NA & - & - & NA \\
\hline Lung-right apical & - & 2.6 & NA & NA & - \\
\hline Lung-left cardiac & - & 3.6 & NA & NA & - \\
\hline BALF & NA & NA & 6.0 & 5.3 & NA \\
\hline Tonsil & 2.4 & 3.4 & 5.0 & 4.5 & - \\
\hline Submandibular lymph nodes & 3.8 & 5.3 & 4.3 & 4.2 & 2.8 \\
\hline Bronchial lymph nodes & - & 3.7 & 3.2 & 4.9 & NA \\
\hline Olfactory bulb & 2.0 & - & - & - & 5.0 \\
\hline Tongue & NA & NA & 2.7 & - & NA \\
\hline
\end{tabular}

NA: Not available; - negative, detected but lower than 2.0. Data displayed were averages of duplicates of each sample. Values shown are $\log _{10}$ copy number/12.5 $\mu \mathrm{L}$ of samples, i.e. $10 \%$ supernatants of tissue homogenates or undiluted samples of BALF.

Table III. Virus isolation on samples positive by real-time RT-PCR for HeV-M from infected Landrace pigs.

\begin{tabular}{|c|c|c|c|c|c|}
\hline & \multirow[t]{2}{*}{ dpi } & \multicolumn{2}{|c|}{$\mathrm{P} 1$} & \multicolumn{2}{|c|}{ P2 } \\
\hline & & RT & VI & RT & VI \\
\hline \multirow[t]{3}{*}{ Oral swabs } & 2 & 3.9 & 8.0 & 3.3 & 1.5 \\
\hline & 4 & 4.2 & 62.8 & 3.9 & 8.0 \\
\hline & 5 & 3.8 & 8.0 & 4.1 & 14.0 \\
\hline \multirow[t]{3}{*}{ Nasal swabs } & 2 & 4.8 & 10.0 & 3.8 & 6.3 \\
\hline & 4 & 5.2 & 444.5 & 4.4 & 62.8 \\
\hline & 5 & 4.0 & 8.0 & 3.8 & 8.0 \\
\hline Rectal swabs & 4 & - & ND & 3.5 & 2.5 \\
\hline Nasal turbinates & & 2.7 & ND & 3.2 & 1.5 \\
\hline BALF & & 4.9 & 79.0 & 4.3 & 25.0 \\
\hline Tonsil & & 3.2 & 8.0 & 3.0 & 1.0 \\
\hline Submandibular lymph nodes & & 4.0 & 8.0 & 3.6 & 4.5 \\
\hline Bronchial lymph nodes & & - & ND & 3.9 & 8.0 \\
\hline
\end{tabular}

RT: HeV-M rRT-PCR, $\log _{10}$ copy number/12.5 $\mu \mathrm{L}$ of sample; VI: virus isolation, $\mathrm{TCID}_{50} / 12.5 \mu \mathrm{L}$ of sample; ND: not detectable; - : negative, detected but lower than 2.0.

Samples were re-frozen and stored at $-70{ }^{\circ} \mathrm{C}$ after the rRT-PCR screening (data in Tab. II).

Samples with negative results on virus isolations for both infected Landrace pigs were not presented.

Table IV. Virus isolation on positive samples detected by real-time RT-PCR for HeV-M from infected minipigs.

\begin{tabular}{|c|c|c|c|c|c|c|}
\hline & \multicolumn{2}{|c|}{ MP4 } & \multicolumn{2}{|c|}{ MP5 } & \multicolumn{2}{|c|}{ MP6 } \\
\hline & RT & VI & RT & VI & RT & VI \\
\hline Nasal turbinates & - & ND & 4.9 & 108.3 & 4.8 & 62.8 \\
\hline Lung-left cardiac & ND & ND & 3.7 & 8.0 & ND & ND \\
\hline Submandibular lymph nodes & 3.1 & 1.5 & 5.0 & 250.0 & ND & ND \\
\hline Bronchial lymph nodes & ND & ND & 4.7 & 62.8 & ND & ND \\
\hline Olfactory bulb & 4.8 & 62.8 & ND & ND & 2.3 & ND \\
\hline
\end{tabular}

See notes in Table III. Samples with negative results on virus isolations for all infected minipigs were not presented. 


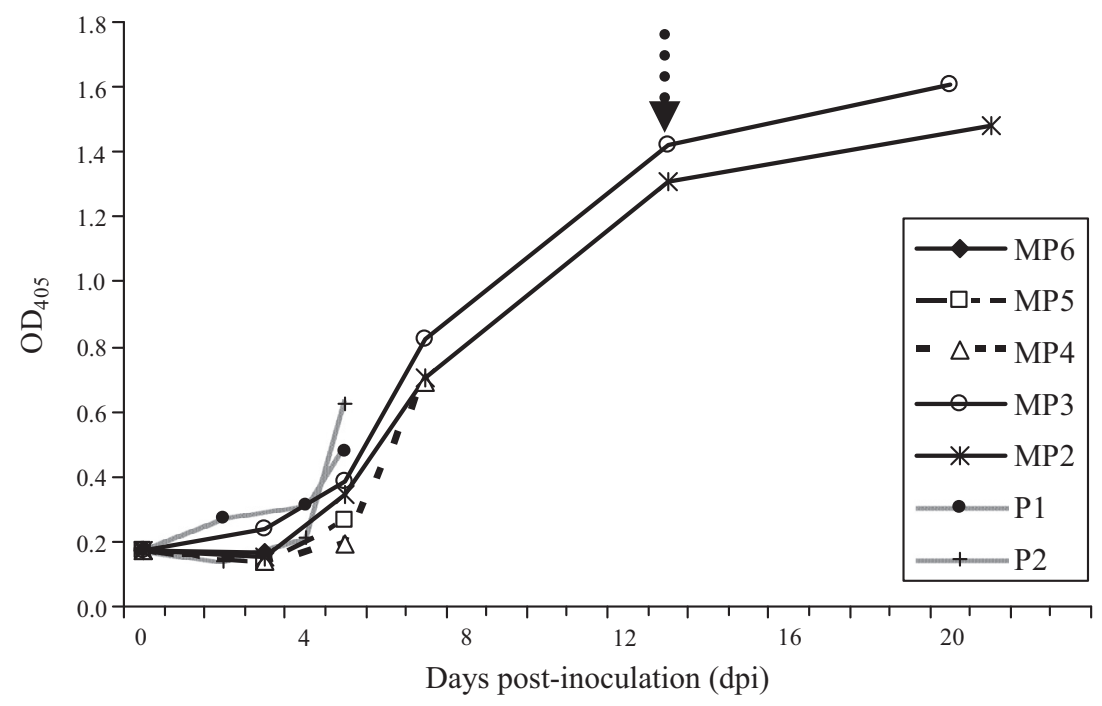

Figure 3. Detection of antibodies against $\mathrm{HeV}$ in serum samples from $\mathrm{HeV}$-infected pigs by indirect ELISA. MP2 to MP6: serum samples from MP2 to MP6; P1 and P2: serum samples from P1 and P2. Data displayed were averages of duplicates of each sample. The arrow indicated the day (13 dpi) when the animals were re-inoculated with $\mathrm{HeV}$.

Table V. Comparison of Hendra and Nipah virus infections in pigs.

\begin{tabular}{|c|c|c|c|}
\hline Virus & & & $\mathrm{NiV}[11,12]$ \\
\hline $\begin{array}{l}\text { Pigs, age, route } \\
\text { and dose of } \\
\text { inoculation }\end{array}$ & $\begin{array}{l}\text { Gottingen minipig, } \\
5 \text {-month-old, } \\
\text { IN } 2.0 \times 10^{7} \mathrm{PFU} / \text { pig }\end{array}$ & $\begin{array}{l}\text { Landrace pig, } \\
5 \text {-week-old, } \\
\text { ON } 6.6 \times 10^{7} \mathrm{PFU} / \text { pig }\end{array}$ & $\begin{array}{l}\text { Landrace pig, } \\
5 \text {-week-old, } \\
\text { ON } 2.5 \times 10^{5} \mathrm{PFU} / \text { pig }\end{array}$ \\
\hline Clinical signs & $\begin{array}{l}\text { Respiratory and } \\
\text { possible neurological }\end{array}$ & Respiratory & $\begin{array}{l}\text { Neurological and mild } \\
\text { respiratory }\end{array}$ \\
\hline Immunohistology & $\begin{array}{l}\text { Frequently noticeable } \\
\text { syncytia }\end{array}$ & $\begin{array}{l}\text { Frequently noticeable } \\
\text { syncytia }\end{array}$ & Rarely noticeable syncytia \\
\hline Virus shedding & Nasal, oral, rectal, ocular & Nasal, oral, rectal, ocular & Nasal, pharyngeal, ocular \\
\hline $\begin{array}{l}\text { Virus distribution } \\
\text { in tissues }\end{array}$ & $\begin{array}{l}\text { Respiratory, lymphoid, } \\
\text { (CNS? - olfactory bulb) }\end{array}$ & Respiratory, lymphoid & Respiratory, lymphoid, CNS \\
\hline
\end{tabular}

CNS: Central nervous system; IN: intra-nasal; and ON: oral and nasal.

On a preliminary level some differences were observed between $\mathrm{HeV}$ and $\mathrm{NiV}$ infections in pigs (Tab. V), particularly in their ability to invade the CNS, which appears to be lower for $\mathrm{HeV}$. However $\mathrm{HeV}$ possibly demonstrated increased virulence for the respiratory tract, illus- trated by the more pronounced respiratory clinical signs than those observed in experimental infections with $\mathrm{NiV}$, as well as the more abundant presence of antigen in the respiratory epithelial cells and more frequently observed syncytia namely in respiratory epithelial cells than in 
$\mathrm{NiV}$ infected pigs [12]. Differences were also observed in virus shedding, where $\mathrm{HeV}$-infected pigs also appear to shed virus via the rectal route.

This study demonstrated that pigs are susceptible to $\mathrm{HeV}$ infection through oro-nasal or nasal inoculations, suggesting that pigs may play a role as an intermediate host for the spreading of the virus to humans if exposed to infected bats which are considered as the natural reservoir of henipaviruses. Since infected pigs may shed virus through oral, nasal, and rectal excretions, possible transmission through close contact with these excretions may occur. Lack of evidence for $\mathrm{HeV}$ infection in domestic swine [4], stresses the importance of heightened on-farm biosecurity. However, our findings may reinforce the concern about $\mathrm{HeV}$ infecting feral pigs if they are forced to share the same habitat as fruit bats. This concern is based on the fact that Australia has over 23 million feral pigs living in Queensland, New South Wales and the Northern Territory, according to reports by Animal Control Technologies ${ }^{2}$.

Acknowledgements. This project was supported by CFIA internal funding. The authors would like to thank Peter Marszal, Greg Smith, Brett Dalman, Brad Collignon, Shelley Ganske and Estella Moffat for their technical assistance, Kevin Tierney and Kimberly Azaransky for the animal care. The authors would also like to thank Marta Sabara for critical review of the manuscript.

\section{REFERENCES}

[1] Anonymous, Call for investment in research and education as another Australian vet dies of Hendra virus, Vet. Rec. (2009) 165:303.

[2] Barclay A.J., Paton D.J., Hendra (equine morbillivirus), Vet. J. (2000) 160:169-176.

[3] Berhane Y., Berry J.D., Ranadheera C., Marszal P., Nicolas B., Yuan X., et al., Production and characterization of monoclonal antibodies against binary ethylenimine inactivated Nipah virus, J. Virol. Methods (2006) 132:59-68.

[4] Black P.F., Cronin J.P., Morrissy C.J., Westbury H.A., Serological examination for evidence of infection with Hendra and Nipah viruses in Queensland piggeries, Aust. Vet. J. (2001) 79:424-426.

$\overline{{ }^{2} \mathrm{http} / / / \text { www.animalcontrol.com.au/pig.htm }}$
[5] Halpine K., Young P.L., Field H.E., Mackenzie J.S., Isolation of Hendra virus from pteropid bats: a natural reservoir of Hendra virus, J. Gen. Virol. (2000) 81:1927-1932.

[6] Mohd Mor M.N., Gan C.H., Ong B.L., Nipah virus infection of pigs in peninsular Malaysia, Rev. Sci. Tech. Off. Int. Epizoot. (2000) 19:160-165.

[7] Murray K., Selleck P., Hooper P., Hyatt A., Gould A., Gleeson L., et al., A morbillivirus that caused fatal disease in horses and humans, Science (1995) 268:94-97.

[8] Reed L.J., Muench H., A simple method of estimating fifty percent endpoints, Am. J. Hyg. (1938) 27:493-497.

[9] Smith I.L., Halpin K., Warrilow D., Smith G.A., Development of a fluorogenic RT-PCR assay (TaqMan) for the detection of Hendra virus, J. Virol. Methods (2001) 98:33-40.

[10] Wang L.F., Yu M., Hansson E., Pritchard L.I., Shiell B., Michalski W.P., Eaton B.T., The exceptionally large genome of Hendra virus: support for creation of a new genus within the family Paramyxoviridae, J. Virol. (2000) 74:9972-9979.

[11] Weingartl H., Czub S., Copps J., Berhane Y., Middleton D., Marszal P., et al., Invasion of the central nervous system in a porcine host by Nipah virus, J. Virol. (2005) 79:7528-7534.

[12] Weingartl H.M., Berhannes Y., Caswell J.L., Loosmore S., Audonnet J.C., Roth J.A., Czub M., Recombinant Nipah virus vaccines protect pigs against challenge, J. Virol. (2006) 80:7929-7938.

[13] Weingartl H.M., Berhane Y., Czub M., Animal models for henipavirus infection: a review, Vet. J. (2009) 181:211-220.

[14] Westbury H.A., Hooper P.T., Sellect P.W., Murray P.K., Equine morbillivirus pneumonia: susceptibility of laboratory animals to the virus, Aust. Vet. J. (1995) 72:278-279.

[15] Williamson M.M., Hooper P.T., Selleck P.W., Gleeson L.J., Daniels P.W., Westbury H.A., Murray P.K., Transmission studies of Hendra virus (equine morbillivirus) in fruit bats, horses and cats, Aust. Vet. J. (1998) 76:813-818.

[16] Williamson M.M., Hooper P.T., Selleck P.W., Westbury H.A., Slocombe R.F., Experimental Hendra virus infection in pregnant guinea-pigs and fruit bats (Pteropus poliocephalus), J. Comp. Pathol. (1999) 122:201-207.

[17] Williamson M.M., Hooper P.T., Selleck P.W., Westbury H.A., Slocombe R.F., A guinea-pig model of Hendra virus encephalitis, J. Comp. Pathol. (2001) 124:273-279. 